\title{
RACJONALNE GOSPODAROWANIE - SCENTRALIZOWANE PRZEWOZY WOJSKOWE
}

\begin{abstract}
Optymalizacja przewozów służy do takiego rozplanowania przewozów, aby koszty transportu były jak najniższe (optymalizacja przewozów znana jest również pod pojęciem zagadnienia transportowe). Dotyczy to głównie jednostek wojskowych, których działalność wymaga dokonywania transportu dużej ilości produktów do zaopatrywania wojska. Planowanie procesów transportowych było i jest jednym $\mathrm{z}$ istotnych zadań w jednostce wojskowej jak również w firmie transportowej. Jego prawidłowa organizacja gwarantuje osiągnięcie oczekiwanych efektów racjonalnego gospodarowania posiadanymi zasobami. Im lepiej będziemy organizować procesy przewozowe, tym bardziej będą zadowoleni nasi klienci (usługobiorcy), co z pewnością przełoży się na osiągnięcie lepszych efektów ekonomicznych. Procesy transportowe z jednej strony muszą być tak organizowane, aby zrealizować wszystkie zlecenie transportowe (czyli dostarczyć ładunek do miejsca odbioru). Jednak z drugiej strony, musimy równocześnie pamiętać, aby podczas planowania procesów transportowych minimalizować koszty ponoszone przez jednostki czy instytucje wojskowe (koszt transportu). W artykule na podstawie przeprowadzonej kwerendy w archiwum Ministerstwa Obrony Narodowej w Modlinie przedstawiono pierwsze próby wprowadzenie scentralizowanych przewozów wojskowych na przykładzie Garnizonu² Rzeszów, w którym w 1979 r. wdrożono program pilotażowy, co oznacz, że pod koniec lat siedemdziesiątych XX. wieku w Wojsku Polskim usiłowano wprowadzić zasady racjonalnego gospodarowania (obniżenie kosztów funkcjonowania wojska). W celu właściwego funkcjonowania scentralizowanych przewozów dowódca garnizonu był zobowiązany do opracowania regulaminu organizacyjnego ich funkcjonowania, wyznaczenia osób funkcyjnych odpowiedzialnych za ich funkcjonowanie.
\end{abstract}

Słowa kluczowe: przewozy wojskowe, Garnizon Rzeszów.

\section{WPROWADZENIE}

Scentralizowane przewozy wojskowe - to forma wykorzystania wojskowego transportu (środków transportowych różnych gałęzi transportu) oparta na jednolitych zasadach planowania i realizacji przewozu osób czy zaopatrzenia ${ }^{3}$.

\footnotetext{
${ }^{1}$ Dr Tadeusz Olejarz, Katedra Nauk Humanistycznych, Politechnika Rzeszowska im. Ignacego Łukasiewicza, ul. Podkarpacka 1, 35-082 Rzeszów, tel.17 743-23-37, e-mail: olejarz@ prz.edu.pl.

${ }^{2}$ Garnizon, jedna lub kilka położonych obok siebie miejscowości, gdzie stale lub okresowo przebywają oddziały różnych rodzajów sił zbrojnych oraz mieszczą się instytucje lub zakłady wojskowe stanowiące załogą garnizonu. Granice garnizonu wyznacza dowódca okręgu wojskowego. Leksykon wiedzy wojskowej, red. M. Laprus, Warszawa 1979, s. 123.

${ }^{3}$ Przewozy zaopatrzeniowe, przemieszczenie (przesunięcie) zapasów środków materiałowych przeznaczonych do zaspokojenia potrzeb sił zbrojnych z jednego rejonu do drugiego za pomocą wszystkich środków transportu. Leksykon wiedzy..., s. 346.
} 
Podczas organizowania procesów przewozowych szczególnie ważne są :

- właściwe dobranie pojazdu i kierowcy do realizacji danego zadania przewozowego,

- wyznaczenie najlepszej trasy przewozu towarów lub ludzi z punktu A do punktu B.

Oczywiście, wymienione powyżej problemy można bardzo prosto rozwiązać, jeśli ma się jeden lub dwa pojazdy i kilka zleceń w ciągu tygodnia. Sytuacja komplikuje się, jeśli posiadamy dużo środków transportu i ogrom środków do przetransportowania. Wówczas planowanie tras czy przydział pojazdu do obsługi danego zlecenia transportowego staje się bardzo skomplikowane oraz czasochłonne. W związku z tym opracowano wiele metod mających na celu wsparcie realizowanych powyżej zadań ${ }^{5}$.

\section{PRZEWOZY WOJSKOWE}

Przewozy wojskowe to nic innego jak, zorganizowane przemieszczanie wojsk lub ładunków wojskowych za pomocą różnych rodzajów transportu ${ }^{6}$ (transport wojskowy ${ }^{7}$ ) na podstawie planów opracowanych przez organy komunikacji wojskowej. Zależnie od rodzaju i przeznaczenia przewozy wojskowe dzielono na:

- przewozy strategiczne,

- przewozy operacyjne,

- przewozy mobilizacyjne,

- przewozy ewakuacyjne,

- przewozy zaopatrzeniowe.

W zależności od rodzaju zastosowanego środka transportu rozróżniano przewozy wojskowe:

- kolejowe,

- wodne (śródlądowe i morskie),

- samochodowe,

- powietrzne,

- kombinowane

- rurociągowe do przemieszczania paliw.

W zależności od zasięgu:

- garnizonowe - organizowane w ramach jednego garnizonu,

- okręgowe - organizowane w ramach jednego okręgu wojskowego,

- przewozy centralne - organizowane na obszarze kilku okręgów wojskowych oraz na obszarze kraju.

\footnotetext{
${ }^{4}$ D. Pyza, Wybrane aspekty modelowania obstugi transportowej w podsystemach dystrybucji, Prace Naukowe Politechniki Warszawskiej, Transport, z. 70/2009, s. 139-140.

${ }_{5}$ M. Blicharz, Wykorzystanie transportu cywilnego do celów obronnych, Zeszyty Naukowe PWSZ w Legnicy 20(3)/2016, s. 7-24.

${ }^{6}$ Transport, red. W. Rydzkowski, K. Wojewódzka-Król, Warszawa 2008, s. 1.

7 Transport wojskowy zespół technicznych środków przewozowych wykorzystywanych w działaniach wojsk i pracy ich tyłów (przewozy wojskowe) w czasie wojny lub pokoju; przewożenie lub przemieszczanie ludzi i ładunków wojskowych. Oddział (pododdział) lub związek wojskowy przewożony w sposób zorganizowany określonymi środkami transportowymi lub pewna liczba (partia) jednorodnych ładunków wojskowych przewożonych do punktu przeznaczenia (np. transport amunicji, broni, sprzętu). Leksykon wiedzy..., s. 459.
} 
Organizacja przewozów wojskowych obejmowała przygotowanie dróg komunikacji, środków transportu, wojsk i ładunków do przewozu, wszechstronne zabezpieczenie przewozów oraz kierowanie nimi. Organizowane były na podstawie planu przewozów wojskowych.

\section{ORGANIZACJA SCENTRALIZOWANYCH PRZEWOZÓW W GARNIZONIE}

Garnizonowe scentralizowane przewozy miały pozwalać na scalenie wszystkich sił i środków, zmniejszenie liczby maszyn, urządzeń oraz osób zaangażowanych w za i wyładunek, co miało przełożyć się na optymalizację procesów transportowych. Do osiągnięcia tak zakładanych celów w Garnizonie Rzeszów powołano Zespół do spraw organizacji scentralizowanych przewozów garnizonowych w składzie ${ }^{8}$ :

- Kwatermistrz Zastępca (Z-ca) Dowódcy (D-cy) Garnizonu Rzeszów - płk dypl. Paweł Strągowski,

- Szef Służb Technicznych Z-ca D-cy Garnizonu Rzeszów - płk inż. Henryk Szczepański,

- Z-ca Kwatermistrza 9. Drezdeńskiej Dywizji Zmechanizowanej (9. DDZ) - mjr dypl. Jerzy Kopeć,

- Szef Służby Czołgowo-Samochodowej 9. DDZ - mjr inż. Jan Szczepan.

Jednostki i instytucje, które zostały objęte scentralizowanymi przewozami na terenie Garnizonu Rzeszów posiadały niżej wymienione możliwości transportowe ${ }^{9}$.

1. Batalion Inżynieryjny Wojsk Obrony Wewnętrznej (JW 3481) ${ }^{10}$ :

- samochód dostawczy ŻUK - 1,

- samochód ciężarowy STAR 29 - 2,

- samochód wywrotka STAR 29W - 2.

2. Jednostki wojskowe podległe bezpośrednio 9. DDZ:

a. 30. Pułk Zmechanizowany (JW 2085)

- samochód dostawczy ŻUK - 1,

- samochód ciężarowy STAR 29 - 2,

- samochód wywrotka STAR 29W - 1,

- traktor z przyczepą - 1 .

b. 29. Batalion Łączności (JW 3514)

- samochód dostawczy ŻUK - 1,

- samochód ciężarowy STAR 29 - 2.

c. 9. Batalion Remontowy (3177)

- samochód dostawczy ŻUK - 1,

- samochód ciężarowy STAR 29 - 1,

- samochód dźwig STAR 29 - 1.

\footnotetext{
8 Archiwum Ministerstwa Obrony Narodowej [dalej: AMON], 2660/10/367, k. 56.

9 Ibidem, k. 56-57.

10 W latach 60. w ramach tworzenia systemu Obrony Terytorialnej Kraju, na bazie przekazanych do MON jednostek Korpusu Bezpieczeństwa Wewnętrznego, utworzono nowy rodzaj wojsk - Wojska Obrony Wewnętrznej. JW 3481 funkcjonowała w latach 1967-1989. Zob. J. Kajetanowicz, Wojska Obrony Terytorialnej Kraju w systemie bezpieczeństwa Polski w latach 1959-1989, „Poligon” 2013, nr 2.
} 
3. Jednostki wojskowe podległe pod dowódcę Warszawskiego Okręgu Wojskowego (WOW) posiadały możliwości transportowe:

a. Garnizonowy Węzeł Łączności Rzeszów (GWŁ)

- samochód dostawczo-osobowy Nysa - 1 .

b. Wojskowy Rejonowy Zarząd Kwaterunkowo-Budowlany Rzeszów (WRZKB)

- samochód ciężarowy STAR 29 - 1,

- samochód wywrotka JELCZ - 1 .

c. Garnizonowa Administracja Mieszkań Rzeszów (GAM)

- samochód dostawczy ŻUK - 1 .

Do realizacji scentralizowanych przewozów garnizonowych wyżej wymienione jednostki i instytucje wojskowe wydzielały siły i środki.

Tabela 1 . Wydzielane siły i środki

\begin{tabular}{|c|c|c|c|c|c|c|c|c|c|c|}
\hline \multirow[b]{2}{*}{$\begin{array}{c}\text { Nazwa } \\
\text { jednostki } \\
\text { i instytucji }\end{array}$} & \multicolumn{2}{|c|}{$\begin{array}{l}\text { Wydzielane } \\
\text { siły }\end{array}$} & \multicolumn{7}{|c|}{ Nazwa sprzętu } & \multirow[b]{2}{*}{$\begin{array}{l}\text { Razem } \\
\text { (sprzęt) }\end{array}$} \\
\hline & 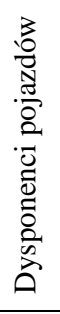 & 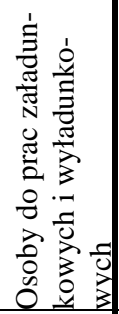 & 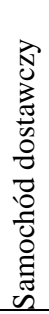 & 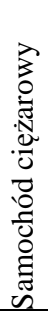 & 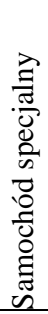 & 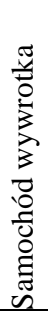 & 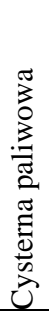 & 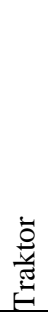 & 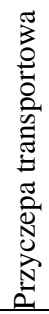 & \\
\hline JW. 3481 & 5 & 15 & 1 & 2 & - & 2 & 1 & - & - & 6 \\
\hline JW. 2085 & 5 & 10 & 1 & 2 & - & 1 & 1 & 1 & 1 & 7 \\
\hline JW. 3514 & 3 & 10 & 1 & 2 & - & - & 1 & - & - & 4 \\
\hline JW. 3177 & 2 & 10 & 1 & 1 & 1 & - & 1 & - & - & 4 \\
\hline GWŁ & 1 & - & 1 & - & - & - & - & - & - & 1 \\
\hline WRZKA & 2 & - & - & 1 & - & 1 & - & - & - & 2 \\
\hline GAM & 1 & - & 1 & - & - & - & - & - & - & 1 \\
\hline Razem & 19 & 45 & 6 & 8 & 1 & 4 & 4 & 1 & 1 & 25 \\
\hline
\end{tabular}

Źródło: opracowanie własne na podstawie AMON, 2660/10/367, k. 56-58.

\subsection{Planowanie przewozów}

Na przewozy garnizonowe do $50 \mathrm{~km}$ od miejsca stacjonowania jednostki i instytucji wojskowej zapotrzebowania składano do Kwatermistrza Z-cy Dowódcy Garnizonu do czwartku każdego tygodnia do godz. 12.00 na tydzień następny. Kwatermistrz po przeanalizowaniu zgłoszonych potrzeb przewozowych i sporządzeniu planu tygodniowego przewozów wydawał zezwolenie na realizację przewozów do piątku każdego tygodnia do godz. 14.00 na następny tydzień.

Na przewozy okręgowe wykonywane pomiędzy garnizonami w zasięgu działania okręgu wojskowego (planowane przez sztab i kierowane przez służbę komunikacji kwatermistrzostwa WOW oraz na przewozy centralne - wykonywane pomiędzy okręgami wojskowymi i Marynarką Wojenną planowane przez Sztab Głównego Kwatermistrzostwa Wojska Polskiego, zapotrzebowania składano do dnia 23 każdego miesiąca na miesiąc następny do Kwatermistrza Garnizonu, który po przeanalizowaniu zapotrzebowań zgłaszał do 
Sztabu Kwatermistrzostwa WOW potrzeby przewozów okręgowych i centralnych w terminie do 24 każdego miesiąca na miesiąc następny.

Instytucje takie jak GAM, WRZKB, Wojskowa Administracja Koszar (WAK) realizujące zaopatrzenie w materiały budowlane (drewno, cement itp.) uzgadniały między sobą terminy dostaw i na tej podstawie składały zapotrzebowania przewozowe ${ }^{11}$.

\subsection{Realizacja przewozów}

Przewozy artykułów żywnościowych (codzienne) - pieczywo, produkty mięsne, mleczarskie, realizowano transportem dostawcy zgodnie ze schematami i harmonogramami opracowanymi przez te instytucje (dostawców) na podstawie złożonych zamówień przy uwzględnieniu wszystkich jednostek i instytucji będących na zaopatrzeniu ${ }^{12}$.

Przewozy artykułów żywnościowych, przedmiotów zaopatrzenia mundurowego, materiałów służby zakwaterowania i budownictwa kilka razy w miesiącu realizowane z garnizonowych źródeł zaopatrzenia (składnic okręgowych) siłami i środkami garnizonowego systemu przewozów, a poza garnizonem siłami i środkami scentralizowanych przewozów garnizonowych na podstawie zgłaszanych potrzeb i opracowanych tygodniowych planów przewozów.

Przewozy garnizonowe zaopatrzenia w materiały pędne i smary (mps) dotyczące rozładunku wagonów-cystern wykonywano siłami i środkami scentralizowanego przewozu wykorzystując transport specjalistyczny.

Realizacja przewozów okresowych i centralnych odbywała się według zasad omówionych w punkcie planowanie przewozów.

Koordynacją i organizacją przewozów w garnizonie kierował Kwatermistrz Z-ca D-cy Garnizonu. Wszelkie uwagi i propozycje dotyczące realizacji przewozów zgłaszano do Z-cy Kwatermistrza, który pełnił nieetatową funkcję dyspozytora scentralizowanych przewozów, do niego także składano i od niego odbierano dokumenty przewozowe.

\subsection{Ewidencja, sprawozdawczość oraz kontrola}

Kwatermistrz Z-ca D-cy zobowiązany był do prowadzenia poprzez nieetatowego dyspozytora następującej dokumentacji:

- tygodniowe plany przewozów garnizonowych - na podstawie złożonych zapotrzebowani,

- książka ewidencji wykonanych prac przewozowych - na podstawie rozkazów wyjazdu.

Dokumenty te stanowiły podstawę do opracowywania przez dyspozytora półrocznych sprawozdań z funkcjonowania scentralizowanych przewozów, które przesyłał do kwatermistrzostwa WOW do 10 lipca za pierwsze półrocze, a do 10 stycznia za drugie półrocze.

Kontrolę funkcjonowania scentralizowanych przewozów w garnizonie przeprowadzano raz na kwartał przez komisję wyznaczaną rozkazem Dowódcy Garnizonu, a ponadto;

- szefowi służby czołgowo-samochodowej i szefowi zaopatrzenia mps nakazano terminowo i dokładnie rozliczać dokumenty przewozowe i przedstawiać Kwatermistrzowi Garnizonu celem sporządzenia dokumentacji zbiorczej,

\footnotetext{
11 AMON, 2660/10/367, k. 58-59.

12 AMON, 2660/10/367, k. 59-60.
} 
- o niedociągnięciach, braku współpracy i niewłaściwym funkcjonowaniu scentralizowanych przewozów osoby funkcyjne miały obowiązek meldowania kwatermistrzowi i dowódcy garnizonu.

\subsection{Zakres działania i obowiązki osób funkcyjnych}

Do podstawowych obowiązków dowódców, kwatermistrzów jednostek i instytucji wojskowych w zakresie planowania przewozów należy zaliczyć ${ }^{13}$ :

- w przewozach garnizonowych zgłaszanie potrzeb przewozowych realizowane było poprzez dostarczenie zapotrzebowania do Kwatermistrza Z-cy D-cy Garnizonu do czwartku każdego tygodnia do godz. 12.00 na następny tydzień.

- w przewozach okręgowych i centralnych zgłoszenie potrzeb przewozowych wykonywano poprzez zgłoszenie zapotrzebowania do Kwatermistrza do 23 każdego miesiąca na miesiąc następny.

- koordynację składania zamówień na dostawy materiałowa pomiędzy poszczególnymi służbami i komórkami organizacyjnymi jednostek uzgadnianie z innymi instytucjami realizującymi przewozy.

W zakresie realizacji przewozów główne zadania to; utrzymywanie wydzielonych środków transport to przewozów scentralizowanych w stałej sprawności technicznej, ścisłe przestrzeganie realizacji planów przewozów w zależności od rodzaju przewozów (garnizonowych, okręgowych i centralnych), maksymalne wykorzystanie ładowności pojazdów, stosowania zestawów drogowych (samochodów z przyczepami itp.), wyposażanie dysponentów-zaopatrzeniowców w odpowiednie dokumenty materiałowe przewożonych materiałów i dokumenty zezwalające użycia pojazdów na określonych trasach, dopilnowanie odpowiedniego wypełniania, prowadzenia i właściwego rozliczenia rozkazów wyjazdów (pracy) oraz dostarczenia ich odpowiednim komórkom rozliczającym, niedopuszczenie do niewłaściwego, niezgodnego z przepisani użycia transportu do innych celów, wydzielanie sił do prac za i wyładowczych zgodnie z odpowiednimi planami przewozów.

\subsection{Obowiązki dysponentów-zaopatrzeniowców}

Żołnierze lub pracownicy cywilni, którym do wykonaniu zadania przewozowego przydzielono wojskowy środek transportu stawali się dysponentami i jednocześnie dowódcami pojazdów, i z tego tytułu do ich obowiązków należało: sprawdzić, czy kierowca jest wypoczęty i zdolny do prowadzenia pojazdu, czuwać nad przestrzeganiem przez kierowcę przepisów ruchu drogowego, nie dopuszczać do spożywania przez kierowcę alkoholu, a w przypadku stwierdzenia, że kierowca spożywał alkohol zakazać prowadzenia pojazdu, wypełnić i podpisać rozkaz wyjazdu po zakończeniu pracy.

Dysponent-zaopatrzeniowiec zobowiązany był zaopatrzyć się w odpowiednie dokumenty zwłaszcza związane $\mathrm{z}$ eksploatacją pojazdu mechanicznego oraz $\mathrm{w}$ dokumenty materiałowe potrzebne do odbioru środków materiałowych i ich przewozu. Pobrać odpowiedni materiał, załadować go na środki transportowe, przewieźć i rozładować w miejscu wskazanym przez dowódcę jednostki czy instytucji wojskowej. W razie konieczności zgłosić potrzeby siły roboczej do rozładunku. Dysponent-zaopatrzeniowiec ponosił całkowitą odpowiedzialność za powstałe braki lub uszkodzenie sprzętu i materiałów powstałe w czasie przewozu.

\footnotetext{
${ }^{13}$ Ibidem, k. 61.
} 


\section{ZAKOŃCZENIE}

Na uwagę zasługuje fakt, że planowano wykonywanie przewozów scentralizowanych po wyjściu jednostek z garnizonu. Przewozy garnizonowe, jak również okręgowe, zamierzano w takim przypadku realizować w oparciu o wydzielony transport przewozowy instytucji wojskowych pozostających w garnizonie według zasad stosowanych w czasie pobytu jednostek w garnizonie $\mathrm{z}$ takim wyjątkiem, że planowane przewozów należało zgłaszać do Wojewódzkiego Sztabu Wojskowego (WSzW) Rzeszów, który przyjmował funkcję organizacyjno-koordynacyjną.

Generalnie można stwierdzić, że stwarzano warunki do funkcjonowania scentralizowanych przewozów garnizonowych w Garnizonie Rzeszów, natomiast w dokumentach archiwalnych ze stycznia $1980 \mathrm{r}$. w protokole przekazania obowiązków kwatermistrza 9. DDZ ${ }^{14}$ znajdujemy zapis, że scentralizowane przewozy praktycznie nie funkcjonują według wymogów rozkazu dowódcy WOW ${ }^{15}$. Pełne ich uruchomienie nastąpiło w 1981 roku.

Wprowadzenie scentralizowanego systemu przewozów pozwoliło na bardziej ekonomiczne wykorzystanie transportu samochodowego. Korygowanie terminów, łączenie przewozów wyeliminowało część tak zwanych pustych przejazdów ${ }^{16}$. W pierwszym półroczu 1981 r. zgłoszonych zostało 711 różnych przewozów; na ich realizację przejechano 177750 km i przewieziono 5445 ton różnego rodzaju środków materiałowych. W tym okresie zaoszczędzono $3900 \mathrm{~km}^{17}$.

System scentralizowanych przewozów był doskonalony w kolejnych latach i obowiązuje w Wojsku Polskim do dnia dzisiejszego.

\section{LITERATURA}

[1] Archiwum Ministerstwa Obrony Narodowej, 2659/10/60, 2660/10/367.

[2] Blicharz M., Wykorzystanie transportu cywilnego do celów obronnych, Zeszyty Naukowe PWSZ w Legnicy 20(3)/2016.

[3] Jóźwiak A., Ziółkowski J., Minimalizacja pustych przebiegów w transporcie wojskowym, Biuletyn WAT, Vol. LXIII, nr 2, 2014.

[4] Kajetanowicz J., Wojska Obrony Terytorialnej Kraju w systemie bezpieczeństwa Polski w latach 1959-1989, „Poligon” 2013, nr 2.

[5] Leksykon wiedzy wojskowej, red. M. Laprus, Warszawa 1979.

[6] Protokół przekazania obowiązków kwatermistrza zastępcy dowódcy 9. Drezdeńskiej Dywizji Zmechanizowanej nr Pf/296 z dnia 5 stycznia 1980 r.

[7] Pyza D., Wybrane aspekty modelowania obstugi transportowej w podsystemach dystrybucji, Prace Naukowe Politechniki Warszawskiej, Transport, z. 70/2009.

[8] Rozkaz Dowódcy WOW nr Pf/226 z dnia 13 grudnia 1978 r.

[9] Transport, red. W. Rydzkowski, K. Wojewódzka-Król, Warszawa 2008.

\footnotetext{
${ }^{14}$ Protokół przekazania obowiązków kwatermistrza zastępcy dowódcy 9. Drezdeńskiej Dywizji Zmechanizowanej $\mathrm{nr} \mathrm{Pf} / 296 \mathrm{z}$ dnia 5 stycznia $1980 \mathrm{r}$.

${ }^{15}$ Rozkaz Dowódcy WOW nr Pf/226 z dnia 13 grudnia 1978 r.

16 A. Jóźwiak, J. Ziółkowski, Minimalizacja pustych przebiegów w transporcie wojskowym, Biuletyn WAT, Vol. LXIII, nr 2, 2014, s. 45-46.

17 AMON, 2659/10/60, k. 204.
} 


\section{RATIONAL MANAGEMENT - CENTRALIZED MILITARY TRANSPORTS}

Transport optimization is used to arrange transport so that transport costs are as low as possible (transportation optimization is also known as transport issues). This applies mainly to military units whose activity involves the transport of large quantities of supplies to the army. Transportation planning has been one of the important tasks in a military unit as well as in a transport company. Its proper organization guarantees the expected effects of rational management of its resources. The better the transport process is organized, the more satisfied customers (recipients) will be, which will surely translate into better economic results. Transportation processes on the one hand must be organized in such a way as to fulfill all transport orders (i.e. deliver cargo to the place of collection). On the other hand, one must also remember that when planning transport processes it is necessary to minimize the costs borne by military units or institutions (transport costs). In an article, on the basis of a query in the archive of the Ministry of National Defense in Modlin, the first attempts were made to introduce centralized military transport on the example of the Garrison Rzeszow, where a pilot program was implemented in 1979, indicating that in the late 1970s in the Polish Army some attempts were made to introduce the principles of rational management (lowering the cost of military operations). For the proper operation of centralized transport, the garrison commander was obliged to develop the organizational regulations for their operation and appoint the functionaries responsible for their operation.

Keywords: military transport, Garrison Rzeszow.

DOI: $10.7862 /$ rz2017.hss.54

Przestano do redakcji: kwiecień $2017 r$.

Przyjęto do druku: wrzesień 2017 r. 